\title{
Assessment of in vitro bioactivities of Pis v 1 (2S albumin) and Pis v 2.0101 (11S globulin) proteins derived from pistachio (Pistacia vera L.)
}

\author{
Seyedeh Faezeh Taghizadeh ${ }^{1} \cdot$ Ramin Rezaee ${ }^{2,3} \cdot$ Masoumeh Mehmandoust $^{4} \cdot$ Hasan Badibostan $^{5}$. \\ Gholamreza Karimi ${ }^{1,5}$ (i)
}

Received: 17 September 2019 / Accepted: 19 December 2019 / Published online: 24 December 2019

○) Springer Science+Business Media, LLC, part of Springer Nature 2019

\begin{abstract}
We studied the biological activity of Pis v 1 (2S albumin) and Pis v 2.0101 (11S globulin) against Coxsackie viruses $(C \mathrm{~V})$ $B 2, B 3, B 4$ and $B 5$ as well as their cytotoxicity against six cell lines. Results showed that the two allergens of pistachio significantly reduce the minimum inhibitory concentration (MIC) and the minimum bactericidal concentration (MBC) against four Gram-positive and four Gram-negative bacteria as well as two fungi. Moreover, they exerted significant in vitro cytotoxic activities against Human ovarian carcinoma (A2780), human colon carcinoma (HTC), human glioblastoma (U-87-MG), human breast adenocarcinoma (MCF-7), and human prostate cell lines (PC3 and DU-145). Our findings revealed that the highest antimicrobial effect of the allergens was found against $M$. loteus $\left(\mathrm{MIC}=10 \mu \mathrm{g} / \mathrm{mL}\right.$ ). The lowest $\mathrm{IC}_{50}$ value was found for Pis v 2.0101 allergen (11S globulin) against $C \mathrm{~V}-B 4(30.20 \pm 1.01 \mu \mathrm{g} / \mathrm{mL})$. Furthermore, in vitro cytotoxicity assay showed $\mathrm{IC}_{50}$ values ranging from $21.09 \pm 0.55$ to $34.52 \pm 0.90$ and $26.34 \pm 0.88$ to $38.63 \pm 0.80 \mu \mathrm{g} / \mathrm{mL}$ for Pis v $2.0101(11 \mathrm{~S}$ globulin) and Pis v 1 (2S albumin), respectively. As these allergens presented considerable effects against biofilm-related infections, $C V-B 2-5$, and several cell lines, they might be employed as alternative/complementary treatments after further preclinical and clinical studies.
\end{abstract}

Keywords Allergen protein - Antibacterial $\cdot$ Anticancer $\cdot$ Antifungal $\cdot$ Antiviral $\cdot$ Pistachio vera L.

Seyedeh Faezeh Taghizadeh and Ramin Rezaee have equally contributed to this work.

\section{Gholamreza Karimi}

KarimiG@mums.ac.ir

1 Pharmaceutical Research Center, Pharmaceutical Technology Institute, Mashhad University of Medical Sciences, Mashhad, P. O. Box, 1365-91775, Islamic Republic of Iran

2 Clinical Research Unit, Faculty of Medicine, Mashhad University of Medical Sciences, Mashhad, Iran

3 Neurogenic Inflammation Research Center, Mashhad University of Medical Sciences, Mashhad, Iran

4 Department of Horticultural Science, Faculty of Agriculture, Islamic Azad University of Shirvan, Shirvan, Iran

5 Department of Pharmacodynamics and Toxicology, Faculty of Pharmacy, Mashhad University of Medical Sciences, Mashhad, Iran

\section{Introduction}

Peptides or proteins are one of the primary "natural antibiotics" which exert considerable antimicrobial effects against a wide range of microorganisms, including Gram-positive and Gram-negative bacteria, yeast, filamentous fungi and to a lesser extent, protozoans and enveloped viruses. Some of these natural antibiotics may be hemolytic and cytotoxic to cancer cells [2]. Plants are valuable sources of compounds that can effectively combat bacterial diseases and tumors. Their role in case of viral disease is contained Corona virus, Coxsackie virus, Dengue virus, Enterovirus, herpes simplex, measles virus respiratory syncytial virus, influenza, human immunodeficiency, hepatitis B and C [36].

Considering chemotherapeutics failure and increasing trend of antibiotic and antiviral resistance, it is essential to search for novel/more efficient antibiotics. Extensive research has been done to discover new alternative antimicrobial and antiviral agents from natural sources [3, 34]. One of the phytochemicals possessing such activities, is proteins [6]. 
Genus Pistacia with approximately ten members, belongs to the family Anacardiaceae [32]. Pistacia vera $\mathrm{L}$. is recognized as a delicious nut with several nutritional benefits [30]. Due to its highly favorable taste, nutritional value, and health promoting composition, it is consumed worldwide as a snack (fresh or roasted and salted), pistachio halva, pistachio milk, pistachio butter, etc. Furthermore, pistachio is normally used as an ingredient in cakes, confectionery products, biscuits, candies, ice creams and chocolates [28, 31]. Pistachio contains various essential nutrients that can contribute to a healthy diet [10]. It means that pistachio allergens are from protein families of $2 \mathrm{~S}$ albumins (Pis $\vee 1$ ), legumins (Pis $\vee 2$ and Pis v 5), vicilins (Pis v3), and iron/ manganese superoxide dismutase (Pis v 4) [11]. It is obvious that certain allergenic proteins, typically those which are stable towards heat and digestion, are the primary cause of an immune response [18]. Characterization of pistachio allergens helps to explain the possible cross-reactivity among tree nut allergens and is the first step towards development of better diagnostic and therapeutic approaches [1].

The Coxsackie viruses of group B (CV-B1-6) is a positive-sense single-stranded RNA virus belonging to Enterovirus genus, and Picornaviridae family. $C \mathrm{~V}-B 1-6$ is known as the most common viral cause of acute and chronic diseases such as human heart infections, and is involved in the development of type I diabetes, myocarditis and central nervous system pathologies, especially among new-born and infants $[5,26]$. From another medicinal point of view, natural compounds have good cytotoxicity profile and their highly selective toxicity makes them promising candidates to be used as adjuvants to anticancer therapeutics to overcome multidrug resistance phenomenon [16].

Various methods have been used for detection of food allergens. The most common quantitative methods used for allergen detection in food, are enzyme-linked immunosorbent assay (ELISA) and real-time PCR. But, it is difficult to detect multiple allergens using an ELISA assay. By using more specific, more quantitative and more sensitive methodologies, trace levels of allergens were also detected in food. As a highly sensitive apparatus, Liquid chromatographymass spectrometry (LC-MS) has been employed to detect multiple allergens in nuts $[18,19]$. To identify peptides, we used a quadrupole time-of-flight (q-TOF) mass spectrometer which enabled us to purify multiple allergens in a short time.

As there are few reports on biological properties of allergenic proteins, we were motivated us to evaluate the (1) antimicrobial, (2) antiviral (against Coxsackie viruses) and (3) cytotoxic effects of allergenic proteins isolated from pistachio.

\section{Materials and methods}

\section{Chemicals and plant material}

The ripe fruits of pistachio (P. vera) ("Kalehghoochi" cultivar) were collected from a commercial orchard of Rafsanjan (at $30^{\circ} 41^{\prime} \mathrm{N}$ and $55^{\circ} 09^{\prime} \mathrm{E} ; 1580.9 \mathrm{~m}$ above sea level), Kerman province, Iran. Kernels, hull and hard shells of fruits were separated and the kernels were air-dried at room temperature, ground and then stored at $4{ }^{\circ} \mathrm{C}$ until analysis. L-Glutamine, penicillin, streptomycin, nystatin, amphotericin B, fetal bovine serum (FBS), Eagle's Minimal Essential Medium (MEM), fetal calf serum (FCS), non-essential amino acids and trypsin were obtained from GIBCO. Hexane, TRIS/HCl, dibasic sodium phosphate, acetonitrile, trifluoroacetic acid (TFA), 3-(4,5-dimethylthiazole-2-yl)2,5-biphenyl tetrazolium bromide (MTT), soybean casein digest agar (SCDA), normal saline (NS), Mueller-Hinton broth (MHB), 2,3,5-triphenyltetrazolium chloride (TTC), Sabouraud's dextrose broth (SDB), phosphate-buffered saline (PBS), dimethyl sulfoxide (DMSO) and RPMI 1640 medium were procured from Sigma Aldrich (Europe).

\section{Protein isolation}

\section{Defatting pistachio powder}

Pistachio kernel powder was extracted using hexane at 1:5 (v:v) ratio and stirred thoroughly for $1 \mathrm{~h}$ at room temperature. The lipid fraction was removed and the precipitate was air-dried in a draft chamber, overnight. The defatting process was repeated in order to produce a completely dried powder. The defatted pistachio kernel powder (DPKP) was stored at $-80{ }^{\circ} \mathrm{C}[9]$.

\section{Protein isolation}

Protein extraction was performed using a slightly modified method that was previously described by Sealey-Voyksner et al. [18]. For this purpose, $30 \mathrm{mg}$ of DPKP was extracted for $2 \mathrm{~h}$ at $50{ }^{\circ} \mathrm{C}$ using $1 \mathrm{~mL}$ of TRIS/ $\mathrm{HCl}(50 \mathrm{mM}, \mathrm{pH} 7.5)$; other solvent used for this purpose were $\mathrm{HCl}(0.01 \mathrm{M}, \mathrm{pH}$ $2.5)$ and dibasic sodium phosphate $(50 \mathrm{mM}, \mathrm{pH} 8)$. The DPKP extracts (with the exception of those subjected to enzymatic digestion) were centrifuged at $8000 \times g$ for $10 \mathrm{~min}$ and the supernatant was collected for analysis by LC-MS for the presence of proteins. For enzymatic digestion, we added trypsin to samples extracted with $50 \mathrm{mM}$ TRIS/HCl (pH 7.5). Also, $25 \mu \mathrm{L}$ of $12 \mathrm{mg} / \mathrm{mL}$ trypsin solution was dissolved in $50 \mathrm{mM}$ sodium phosphate and the mixture was added to the samples and incubated at $38{ }^{\circ} \mathrm{C}$ for $2 \mathrm{~h}$ while 
vortexed every $15 \mathrm{~min}$; after this time, $200 \mu \mathrm{L}$ of acetonitrile with $0.2 \%$ TFA was added to the sample. The digested sample was centrifuged at $8000 \times g$ for $10 \mathrm{~min}$ and the upper $200 \mu \mathrm{L}$ was fractionated into a 96-well plate for LC-MS/ MS analysis [18].

\section{Liquid chromatography-mass spectrometry (LC- MS)}

Liquid chromatography-mass spectrometry (LC-MS) for pistachio proteins and trypsin digest analysis, was carried out by an Agilent 1290 LC system (Agilent Santa Clara, CA, USA) coupled with an Agilent 6530 quadrupole timeof-flight (q-TOF) mass spectrometer to identify peptides that represent known pistachio proteins.

\section{Protein analysis}

The DPKP proteins were separated on an Agilent Poroshell 300 column $\left(2.1 \times 75 \mathrm{~mm}, 2.7 \mu \mathrm{m}, 300 \mathrm{~A}^{\circ}\right.$; Agilent, Santa Clara, CA, USA, using a gradient of 0 to $40 \%$ of solution I for 70 min (solution I comprised of $95 \%$ water $+5 \%$ acetonitrile $+0.025 \%$ TFA) and solution II (solution II comprised of $5 \%$ water $+95 \%$ acetonitrile $+0.025 \%$ TFA), then from $40 \%$ solution II to $60 \%$ solution II at $80 \mathrm{~min}$ at a flow rate of $0.3 \mathrm{~mL} / \mathrm{min}$. The temperature of column was held at $30{ }^{\circ} \mathrm{C}$ for the analysis. The injection volume was $20.0 \mu \mathrm{L}$.

For q-TOF-MS operation, the electrospray positive ion detection mode was set up in $2 \mathrm{GHz}$ extended dynamic range mode. The duration of scanning was $0.5 \mathrm{~s}$ from $\mathrm{m} / \mathrm{z}, 300$ to 2800 . The electrospray characteristics were: drying gas $350{ }^{\circ} \mathrm{C}$ at $9 \mathrm{~L} / \mathrm{min}$, nebulizer gas (nitrogen; flow $10 \mathrm{~L} / \mathrm{min}$ ) and sheath gas $350{ }^{\circ} \mathrm{C}$ at $11 \mathrm{~L} / \mathrm{min}$, capillary voltage $4000 \mathrm{~V}$, nozzle voltage $1000 \mathrm{~V}$, and fragmentor voltage $160 \mathrm{~V}$.

\section{Peptide analysis}

The digested sample was analyzed by an Agilent Poroshell 120 column $(2.1 \times 50 \mathrm{~mm}, 2.7 \mu \mathrm{m})$ using a gradient of $0-40 \%$ solution II for 70 min then $40-60 \%$ solution II for $80 \mathrm{~min}$ with a flow rate of $0.25 \mathrm{~mL} / \mathrm{min}$. The column temperature for the analysis was $30^{\circ} \mathrm{C}$ and the injection volume was $20 \mu \mathrm{L}$. The q-TOF-MS operation was conducted as in a same way as that done for protein analysis. The auto MS/MS was also operated for the most intense precursor ions that were selected via single MS before, by considering $>15,000$ counts from 600 to $2100 \mathrm{~m} / z$. For MS/MS, nitrogen was used as collision gas and the collision energy was $10 \mathrm{eV}$. The MS/ MS spectrum was operated in the positive ion as follows: Agilent at $3 \mathrm{spectra} / \mathrm{sec}$ over $60-2100 \mathrm{~m} / z$ with capillary voltage $4000 \mathrm{~V}$, nozzle voltage $1000 \mathrm{~V}$, fragmentor voltage $160 \mathrm{~V}$, and collision energy of $10 \mathrm{eV}$.

\section{Detection in database}

The Agilent technology (The Spectrum Mill MS Proteomics, workbench Rev B.04.00127) was used to search the database. Searches were based on a mass tolerance window of $20 \mathrm{ppm}$ for precursor ion and $50 \mathrm{ppm}$ window for the product ions around the measured $\mathrm{m} / \mathrm{z}$. The search used trypsin digestion with up to two missed cleavages with no modifications. The LC-MS data from the tryptic digests of pistachio proteins were searched to identify peptide sequences from the major peaks in the LC-MS run and to match the identified peptide to a specific pistachio protein. A MS scoring algorithm was used to match ions present in the spectrum with the sequence based upon factors described by Kapp et al. [13]. Scores of 15 and above are well assigned fragmentation and correct interpretation. Scores that were greater than 10 were very good and usually right. Spectrum Mill was used to confirm the amino acid sequences based on the acquired MS spectra as a secondary confirmation of the postulated sequence. Spectrum Mill was also used to verify that these sequences were unique to the pistachio analyzed (based on the search sequence in the green plant NCBInr database using MS Edman program) and would not be found in other nuts or green plants. The sequencing process was done at Department of Molecular Biochemistry, Faculty of Chemistry, University of Gdańsk, Poland [18].

\section{Peptide standards}

High resolution MS/MS was used to confirm the identity of the peptide. All the peptide standards (2S albumin MS Spec standard: CAT No. A8471; and 11S globulin Analytical Standard: CAT No. P8119) were purchased from Sigma Aldrich (Europe).

In order to make $1 \mathrm{mg} / \mathrm{mL}$ stock solution, each peptide was dissolved in water: acetonitrile (80:20 ratios) then, diluted to make the threshold standard of $0.1 \mathrm{ppm}$.

\section{Protein content}

Protein was quantified by Bradford assay. The assay calibration was set over the range of $25-2000 \mu \mathrm{g} / \mathrm{mL}$ and bovin albumin was used as the standard protein.

\section{Antimicrobial activity}

\section{Strains and growth condition}

DPKP-isolated allergens' antimicrobial properties were examined against 4 Gram-positive [Staphylococcus aureus (PTCC (Persian Type Culture Collection) 1431), Staphylococcus epidermidis (PTCC 1435), Micrococcus luteus (ATCC (American Type Culture Collection) 9341) and 
Bacillus cereus (PTCC 1247)], 4 Gram-negative [(Pseudomonas aeruginosa (PTCC 1074), Salmonella typhi (PTCC 1609), Serratia marcescens (PTCC 1267) and Escherichia coli (ATCC 1533)] bacteria and 2 fungi [(Candida albicans (ATCC 10231) and Aspergillus niger (ATCC 16404)]. A fresh culture media for each microorganism was prepared separately. For bacterial strains, the culture media was prepared through $24 \mathrm{~h}$ incubation at $37^{\circ} \mathrm{C}$ on SCDA and the bacterial population was adjusted to $10^{6} \mathrm{CFU} / \mathrm{mL}$ using normal saline (NS $0.9 \%$ ). Then, microorganisms were cultured at $25^{\circ} \mathrm{C}$ for $48 \mathrm{~h}$ on SCDA, and adjusted to $10^{6} \mathrm{CFU} / \mathrm{mL}$ by sterile $0.9 \%$ NS to be tested against fungal strains [33].

\section{Minimum inhibitory concentration and minimum bactericidal and fungicidal concentrations}

Minimum inhibitory concentration (MIC) of DPKP-isolated allergens was determined by the micro-dilution method using 96-microwell culture plates. Accordingly, in order to prepare the first concentration $(10 \% \mathrm{v} / \mathrm{v})$ of each DPKPisolated allergen, $650 \mu \mathrm{L}$ of each allergen was added to 325 $\mu \mathrm{L}$ DMSO and the final volume of the mixture was adjusted to $6.5 \mathrm{~mL}$ using MHB. The other concentrations of DPKPisolated allergens were made by using two-fold serial dilution method. A mixture of $200 \mu \mathrm{L}$ of each concentration of DPKP-isolated allergens and $20 \mu \mathrm{L}$ of bacterial suspension $\left(10^{6} \mathrm{CFU} / \mathrm{mL}\right)$, was added to each well of a $96-$ well culture plate. For each bacterium, the experiment was done in duplicate. Also, MHB with DMSO and the microorganisms (with exception DPKP-isolated allergen) served as the negative control. After $24 \mathrm{~h}$ incubation at $37{ }^{\circ} \mathrm{C}, 20 \mu \mathrm{L}$ of TTC $(5 \mathrm{mg} / \mathrm{mL})$ was added to each well for bacterial growth estimation. The lowest concentration of the DPKP-isolated allergens inhibiting the formation of red color in culture media was considered the minimum inhibitory concentration (MIC). In addition, the minimum bactericidal concentration (MBC) was measured by incubation of $20 \mu \mathrm{L}$ of colorless content with Mueller-Hinton agar media, for $24 \mathrm{~h}$ at $37^{\circ} \mathrm{C}$. Gentamicin and vancomycin were applied as the positive control against Gram-positive and Gram-negative bacteria, respectively [29].

To investigate the anti-fungal activity of DPKP-isolated allergens, different concentrations of DPKP-isolated allergens were prepared as previously mentioned in the antimicrobial assay. The volume was adjusted to $1 \mathrm{~mL}$ by SDB. Using twofold serial dilution technique, other concentrations of DPKPisolated allergens were prepared. Then, $200 \mu \mathrm{L}$ of cell suspension $\left(10^{6} \mathrm{CFU} / \mathrm{mL}\right)$ was incubated for $48 \mathrm{~h}$ at $25^{\circ} \mathrm{C}$. Finally, the concentration with no visible microbial growth (i.e. MIC) and the concentration with no visible fungal growth [i.e. minimum fungicidal concentration (MFC)] were determined. In this experiment, the negative and positive controls were treated with SDB and nystatin, respectively [22].

\section{Antiviral activity}

The Coxsackie viruses (CV) B2, B3, B4 and B5 were propagated in HEp-2 cells provided from National Cell Bank of Iran (Pasteur Institute, Tehran, Iran). Then, they were maintained in MEM supplemented with $10 \%$ heat-inactivated fetal calf serum (FCS), $1 \%(2 \mathrm{mM})$ L-Glutamine, $1 \%(50 \mu \mathrm{g} / \mathrm{mL})$ streptomycin, $1 \%(50 \mathrm{IU} / \mathrm{mL})$ penicillin, $1 \%$ non-essential amino acids and $1 \%(2.5 \mu \mathrm{g} / \mathrm{mL})$ amphotericin $\mathrm{B}$. The viruses titer was determined based on the $50 \%$ tissue culture infectious dose $\left(\mathrm{TCID}_{50}\right)$ on HEp-2 cells and all viruses were stored at $-80^{\circ} \mathrm{C}$ until use. The antiviral activity of DPKP-isolated allergens against $C \mathrm{~V} B 2, B 3, B 4$ and $B 5$ was studied with respect to their inhibitory activity on virus-induced cytopathogenicity and cell death in HEp-2 cells. HEp- 2 cells were seeded into 96-well plates at $10^{4}$ cells/well at $37{ }^{\circ} \mathrm{C}$ with $5 \% \mathrm{CO}_{2}$. After $24 \mathrm{~h}$, the culture media was removed, and cells were washed two times with PBS before adding $100 \mu \mathrm{L}$ of each DPKP-isolated allergen mixed with MEM $2 \%$ FCS (twofold dilutions, ranging from 3.9 to $1000 \mu \mathrm{g} / \mathrm{mL}$ ). Cells were inoculated with $50 \mu \mathrm{L}$ of $2 \%$ MEM containing $100 \mathrm{TCID}_{50}$ of each Coxsackie virus (B2$B 5)$. The MTT assay was performed for investigation of cell death due to virus infection. The virus inhibition percentages were measured using the following equation:

Virus inhibition $(\%)=\frac{(T-V c)}{(C c-V c)} \times 100$

where $\mathrm{T}$ is the optical density (OD) of cells treated with DPKP-isolated allergens, $\mathrm{Vc}$ is the OD of virus control, and $\mathrm{Cc}$ is the OD of cell control. The antiviral activity curve was then generated by plotting virus inhibition percentages against DPKP-isolated allergens concentrations. The concentration that could reduce $50 \%$ of cytopathic effect (CPE) with respect to the virus control (cells that were infected only with the virus, but not treated with the compound in the antiviral assays), was estimated from plots of the data and defined as $50 \%$ inhibitory concentration $\left(\mathrm{IC}_{50}\right)$. Another important issue was to determine the selectivity index (SI) towards the host cell. The SI was defined as the ratio of the maximum concentration causing either 50\% inhibition of growth of normal cells $\left(\mathrm{CC}_{50}\right)$ to the minimum concentration at which $50 \%$ of the virus is inhibited $\left(\mathrm{IC}_{50}\right)$ [26].

\section{Cytotoxicity assay}

\section{Cell culture}

Human ovarian carcinoma (A2780), human colon carcinoma (HTC), human glioblastoma (U-87-MG), human 
breast adenocarcinoma (MCF-7), and human prostate cell lines (PC3 and DU-145) were purchased from National Cell Bank of Iran (Pasteur Institute, Tehran, Iran). All cells were maintained at $37{ }^{\circ} \mathrm{C}$ in humidified (90\%) atmosphere with $5 \% \mathrm{CO}_{2}$ in RPMI 1640-supplemented with $10 \%$ (v/v) FBS, $100 \mathrm{IU} / \mathrm{mL}$ penicillin and $100 \mathrm{mg} / \mathrm{mL}$ streptomycin.

\section{Cell viability assay}

Cytotoxicity of DPKP-isolated allergens against human cancer cell lines was examined using MTT assay. Also, 3T3 was used as a normal cell line. Briefly, the cells $\left(5 \times 10^{3}\right.$ per well) were seeded in a 96-well plate; after $24 \mathrm{~h}$, for adhesion, different concentrations of each DPKP-isolated allergens were added to wells and all experiments were done in triplicate. After $48 \mathrm{~h}$ incubation, $10 \mu \mathrm{L}$ of MTT $(5 \mathrm{mg} / \mathrm{mL}$ stock solution) was added to each well and the plates were incubated at $37^{\circ} \mathrm{C}$ for $4 \mathrm{~h}$. The medium was removed and the formazan blue crystals were dissolved by $200 \mu \mathrm{L}$ DMSO. The absorbance was measured at $570 \mathrm{~nm}$ by an ELISA microplate reader (Awareness Technology, Inc., Palm City, FL, USA). Cytotoxicity of each DPKP-isolated allergen was presented as its concentration inhibiting cell growth by $50 \%\left(\mathrm{IC}_{50}\right)$ and the percentage of viable cells was determined using the following equation ([21]:

Viable cell $(\%)=\frac{(A t c-A b)}{(A c-A b)} \times 100$

where Atc, Ab, Ac are the absorbance of the treated cells, blank and control cells, respectively.

\section{Statistical analysis}

Statistical analysis was performed as a completed randomized design (CRD) in triplicate and data are presented as mean $\pm \mathrm{SD}$. One way analysis of variance (ANOVA) and LSD test were performed to determine statistical differences among groups by JMP 8 (SAS Campus Drive, Cary, NC 27513) and Sigma Plot 12 software. The $\mathrm{IC}_{50}$ values were determined by GraphPad Prism 5.0 (GraphPad software, San Diego, CA, USA). Significant differences among mean values were determined by using LSD at the level of 0.05 .

\section{Results}

\section{Pistachio allergenic proteins purification}

\section{Method validation and protein content}

Protein content of each fraction was estimated using the Bradford assay. As shown in Table 1, among three solvents used (i.e. $50 \mathrm{mM}$ TRIS/HCl, pH 7.5; $0.01 \mathrm{M} \mathrm{HCl} \mathrm{pH} 2.5$ and $50 \mathrm{mM}$ dibasic sodium phosphate, $\mathrm{pH} 8$ ), the highest yields of protein extraction was recorded for TRIS/HCl; however, the difference between TRIS/HCl and dibasic sodium phosphate was not statistically significant $\left(\mathrm{p}^{<} 0.05\right)$. $\mathrm{HCl}$ could not completely extract the high molecular weight proteins. The Bradford assay indicated that protein contents of TRIS/ $\mathrm{HCl}$ and dibasic sodium phosphate fractions were 77.4 and $70.2 \%$ with recovery of 90.2 and $89.3 \%$ of DPKP on a weight basis, respectively. Nevertheless, the $\mathrm{HCl}$ extract contained $33.5 \%$ total protein, and the percentage of its recovery represented $89.1 \%$ of DPKP on a weight basis.

\section{Proteins purification and peptide markers}

The DPKP mass spectra taken at different retention time points showed numerous homogenous peaks with distinctive multiply charged ions that could easily determine the molecular weight.

Using our multiplexed LC-MS/MS analytical method, two marker peptides were detected based on retention times, accurate mass (in a $10 \mathrm{ppm}$ window) and the product ions. The initial step in peptide selection included identification of the peptides. Among different detected proteins, two allergens are shown in Table 2 and Figs. 1 and 2.

\section{Antimicrobial activity}

\section{MIC and MBC values}

The antimicrobial activity of each DPKP-isolated allergen, namely Pis v 1 (allergen 2S albumin) and Pis v 2.0101 (allergen $11 \mathrm{~S}$ globulin), was examined against eight bacteria and two fungi (Table 3). According to the results, Pis v 1 and Pis v 2.0101 had similar MIC and MBC values of 16 and $12 \mu \mathrm{g} / \mathrm{mL}$, respectively against $S$. epidermis. Also, it was observed that the most sensitive strain to these allergens was S. epidermis. Moreover, both allergens had similar MIC and MFC values of 12 and $10 \mu \mathrm{g} / \mathrm{mL}$, respectively against $C$. albicans. In terms of antifungal activity, significant differences were observed between the allergens (Table 3). Based on our results, MIC and MFC values against $C$. albicans and

Table 1 Total protein content and percentage of recovery in different fractions

\begin{tabular}{lll}
\hline Fractions & $\begin{array}{l}\text { Protein by weight on dry } \\
\text { basis (\%) }\end{array}$ & Recovery (w/w\%) \\
\hline TRIS/HCl & $77.4 \pm 2.1$ & $90.2 \pm 1.5$ \\
$\mathrm{HCl}$ & $33.5 \pm 1.9$ & $89.1 \pm 1.5$ \\
$\begin{array}{l}\text { Dibasic sodium } \\
\text { phosphate }\end{array}$ & $70.2 \pm 2.1$ & $89.3 \pm 1.3$ \\
\hline
\end{tabular}


Table 2 Pistachio allergenic proteins profiles

\begin{tabular}{|c|c|c|c|c|c|c|c|c|}
\hline Peptide marker & Sequence & $\mathrm{RT}^{\mathrm{a}}(\min )$ & $\begin{array}{l}\text { Accurate mass } \\
(\mathrm{m} / \mathrm{z})\end{array}$ & $\begin{array}{l}\text { MS/MS } \\
\text { sequence }\end{array}$ & MS/MS mass & Protein name & $\begin{array}{l}\text { Allergen content } \\
(\mathrm{mg})\end{array}$ & $\begin{array}{l}\text { Protein } \\
\text { MW } \\
(\mathrm{KDa})\end{array}$ \\
\hline pis2 & LQELYETASELPR & 25.5 & 774.9005 & 19.4 & 1064.334 & $\begin{array}{l}\text { Pis v } 1 \text { allergen } \\
2 \mathrm{~s} \text { albumin }\end{array}$ & $1.2 \pm 0.03$ & 17.300 \\
\hline Pis 1 & TNGLSQTSQLAGR & 13.0 & 666.8486 & 19.8 & 1307.123 & $\begin{array}{l}\text { Pis v } 2.0101 \\
\quad \text { allergen } 11 \mathrm{~s} \\
\text { globulin }\end{array}$ & $2.3 \pm 0.03$ & 56.470 \\
\hline
\end{tabular}

${ }^{\mathrm{a}}$ Retention time

Fig. 1 Mass spectrum of Pis v 2.0101 allergen $11 \mathrm{~s}$ globulin

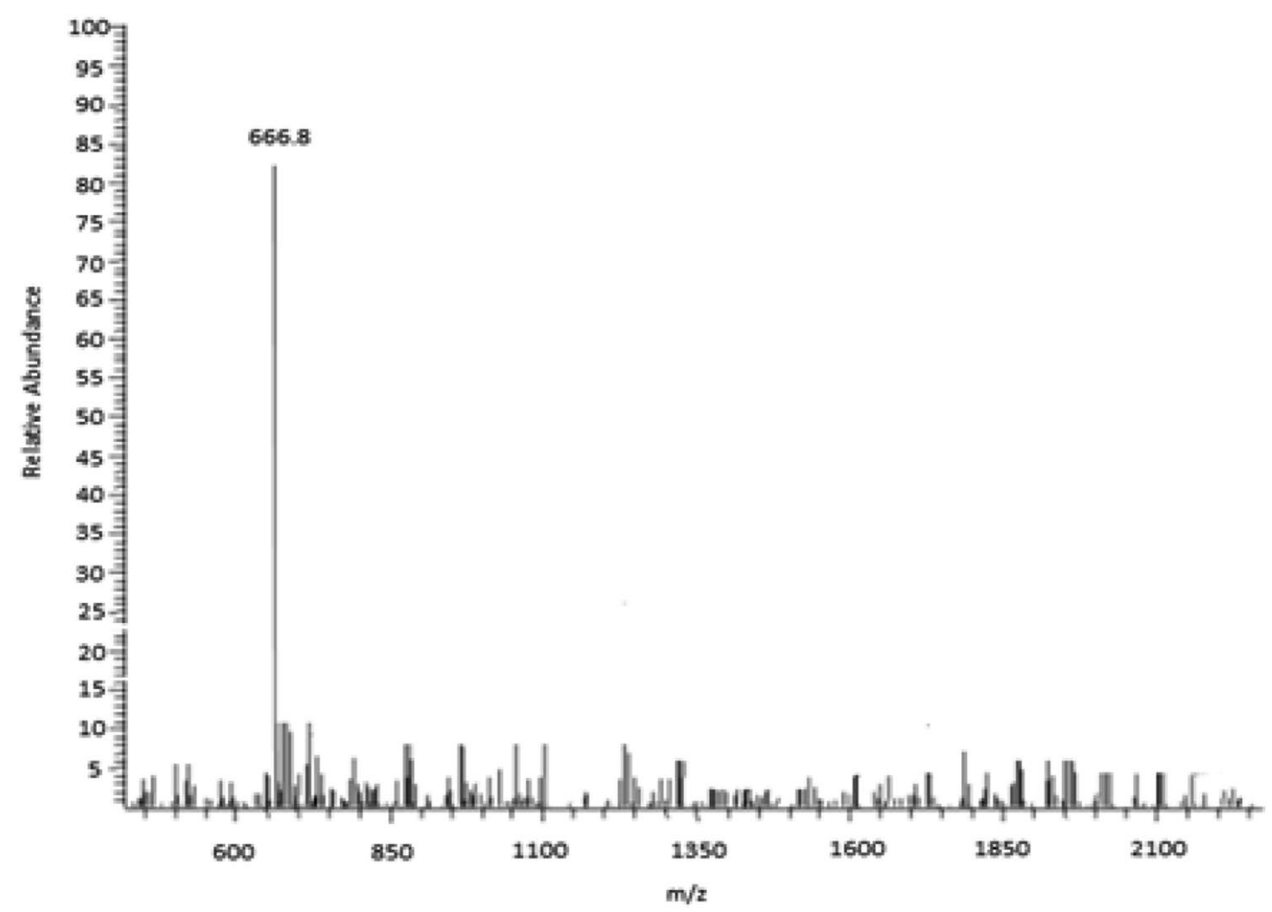

A. niger for Pis v 2.0101 were similarly 10 and $50 \mu \mathrm{g} / \mathrm{mL}$, respectively (Table 3 ).

\section{Antiviral activity}

\section{Inhibition of Coxsackie viruses (CV-B2-5) infectivity by DPKP-isolated allergens}

The antiviral activity of different concentrations of the two allergens was evaluated against Coxsackie viruses (B2-B5) at $37{ }^{\circ} \mathrm{C}$ (Fig. 3). The virus assay examined the inhibitory effects of the compounds on virus- induced pathogenicity in HEp- 2 cells. Our results proved that both of these allergens are active against Coxsackie viruses (B2-B5) and the lowest $\mathrm{IC}_{50}$ values for both allergens were observed for $C \mathrm{~V}-B 4$. $\mathrm{IC}_{50}$ values calculated for Pis v 2.0101 were significantly lower than those of Pis v 1 against all cell lines (Table 4). The selectivity indexes (SI) $\left(\mathrm{CC}_{50} / \mathrm{IC}_{50}\right)$ of both allergens for all CVs were $>3$. Generally, $50 \%$ cytotoxic concentration $\left(\mathrm{CC}_{50}\right)$ is considered a useful marker in cytotoxicity. Based on our results, the $\mathrm{CC}_{50}$ of Pis v 2.0101 against all cell lines was $710.30 \pm 1.03$ (Table 4). A $\mathrm{CC}_{50}$ of $100-1000 \mu \mathrm{g} /$ $\mathrm{mL}$ shows moderate cytotoxicity. It seems that the antiviral activity is appropriate when the samples tested have an $\mathrm{IC}_{50}$ values below $100 \mu \mathrm{g} / \mathrm{mL}$ [4].

\section{Cytotoxicity}

Cytotoxicity of the two isolated allergens was investigated using MTT method against six human cancer cell lines (Table 5). Doxorubicin was used as the positive control. The results are summarized in Table 5. Both allergens had potent cytotoxic effects toward all cancer cell lines at all tested concentrations $\left(\mathrm{IC}_{50}\right.$ values $\left.<100 \mu \mathrm{g} / \mathrm{mL}\right)$. Comparison made between the two allergens showed that $\mathrm{IC}_{50}$ values of Pis v 
Fig. 2 Mass spectrum of Pis v 1 allergen $2 \mathrm{~s}$ albumin
Table 3 MICs and MBCs of Pis v 1 and Pis v 2.0101 against different bacterial and fungal strains

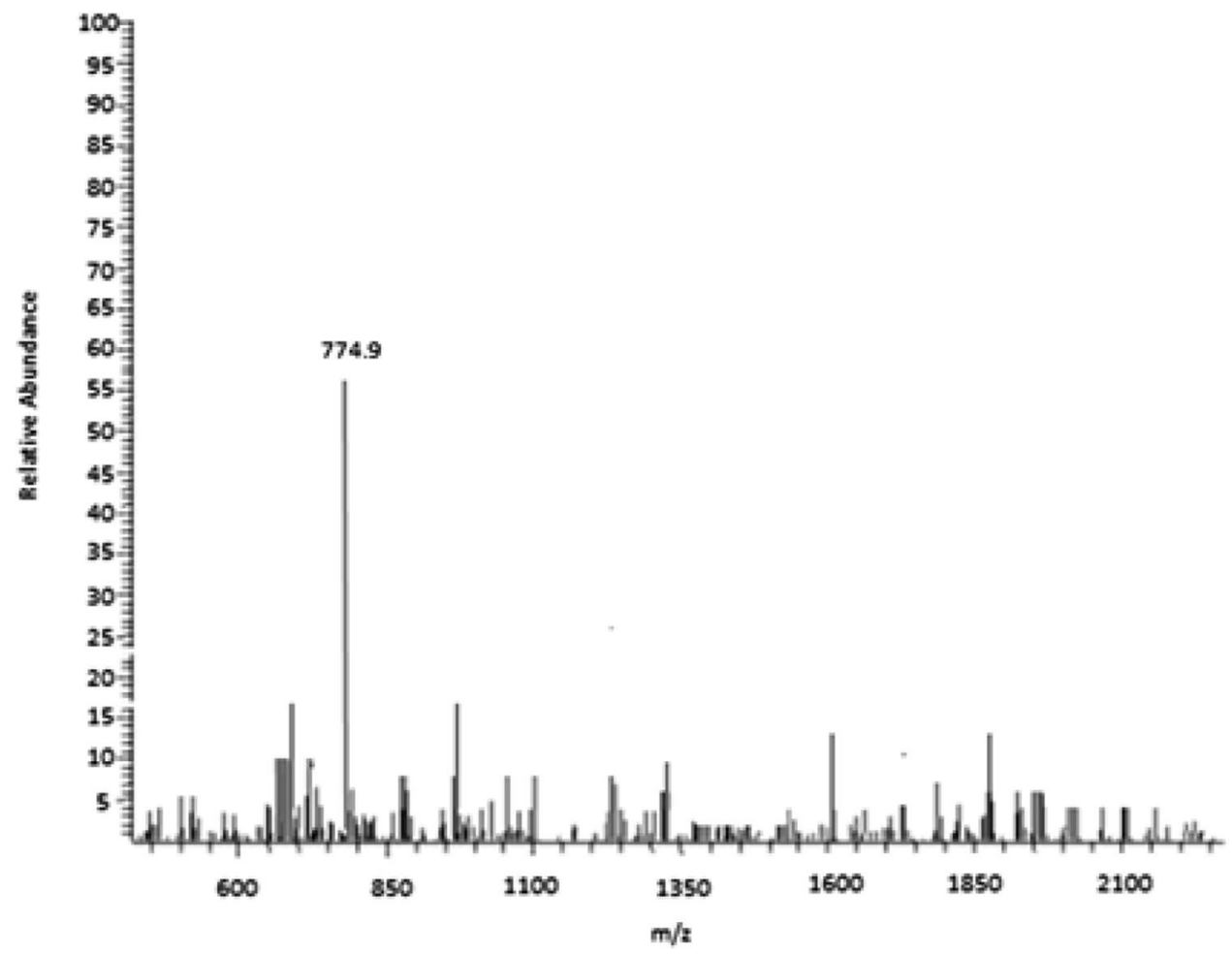

\begin{tabular}{|c|c|c|c|c|c|c|c|c|c|c|}
\hline \multirow{2}{*}{$\frac{\text { Microorganism }}{\text { Bacterial strains }}$} & \multicolumn{2}{|c|}{ Pis v 1} & \multicolumn{2}{|c|}{ Pis v 2.0101} & \multicolumn{2}{|c|}{ Gentamicin } & \multicolumn{2}{|c|}{ Vancomycin } & \multicolumn{2}{|c|}{ Nystatin } \\
\hline & $\mathrm{MIC}^{\mathrm{a}}$ & $\mathrm{MBC}^{\mathrm{b}}$ & MIC & $\mathrm{MBC}$ & MIC & $\mathrm{MBC}$ & MIC & $\mathrm{MBC}$ & MIC & MBC \\
\hline S. aureus (PTCC 1431) & 50 & 105 & 12 & 25 & - & - & 4 & 32 & - & - \\
\hline S. epidermis (PTCC 1435) & 16 & 16 & 12 & 12 & - & - & 2 & 24 & - & - \\
\hline B. cereus (PTCC 1247) & 80 & 140 & 6.25 & 13.5 & - & - & 4 & 80 & - & - \\
\hline M. luteus (ATCC 9341) & 16 & 16 & 10 & 22 & - & - & 2 & 40 & - & - \\
\hline E. coli (ATCC 1533) & 90 & 90 & 50 & 112 & 8 & 8 & - & - & - & - \\
\hline P. aeruginosa (PTCC 1074) & 120 & 250 & 80 & 145 & 16 & 16 & - & - & - & - \\
\hline $\begin{array}{l}\text { S. typhi (PTCC 1609) } \\
\text { S. marcescens (PTCC 1267) }\end{array}$ & $\begin{array}{l}92 \\
120\end{array}$ & $\begin{array}{l}180 \\
120\end{array}$ & $\begin{array}{l}60 \\
60\end{array}$ & $\begin{array}{l}90 \\
73.2\end{array}$ & $\begin{array}{l}16 \\
8\end{array}$ & $\begin{array}{l}16 \\
8\end{array}$ & - & - & - & - \\
\hline Fungal strains & MIC & $\mathrm{MFC}^{\mathrm{c}}$ & MIC & MFC & MIC & MFC & MIC & MFC & MIC & MFC \\
\hline C. albicans (ATCC 10231) & 12 & 12 & 10 & 10 & - & - & - & - & 4 & 4 \\
\hline A. niger (ATCC 16404) & 20 & 30 & 50 & 50 & - & - & - & - & 8 & 8 \\
\hline
\end{tabular}

${ }^{\mathrm{a}}$ Minimum inhibitory concentration $(\mu \mathrm{g} / \mathrm{mL})$

${ }^{\mathrm{b}}$ Minimum bactericidal concentration $(\mu \mathrm{g} / \mathrm{mL})$

${ }^{\mathrm{c}}$ Minimum fungicidal concentration $(\mu \mathrm{g} / \mathrm{mL})$

2.0101 were significantly lower than those of Pis v 1 against all cell lines (Table 5).

\section{Discussion}

Since synthetic antibiotics have become less effective or even ineffective, peptides have been considered for development of new antibiotics. Many peptides are known to play important roles in immunomodulation, promotion of wound healing during the clearance of infection, and antiviral activity against HIV-1. They can incorporate into the eukaryotic cells and interact with the members of mitochondria inducing membrane depolarization and tumor cell death via activation of mitochondrial apoptotic pathways [20]. In the present work, we found that these allergens have considerable antimicrobial effects against Gram-positive, Gramnegative and fungal as well as Coxsackie viruses and possess A2780, HTC, U-87-MG, MCF-7, PC3, DU-145 cytotoxic properties. It was previously shown that melittin isolated 

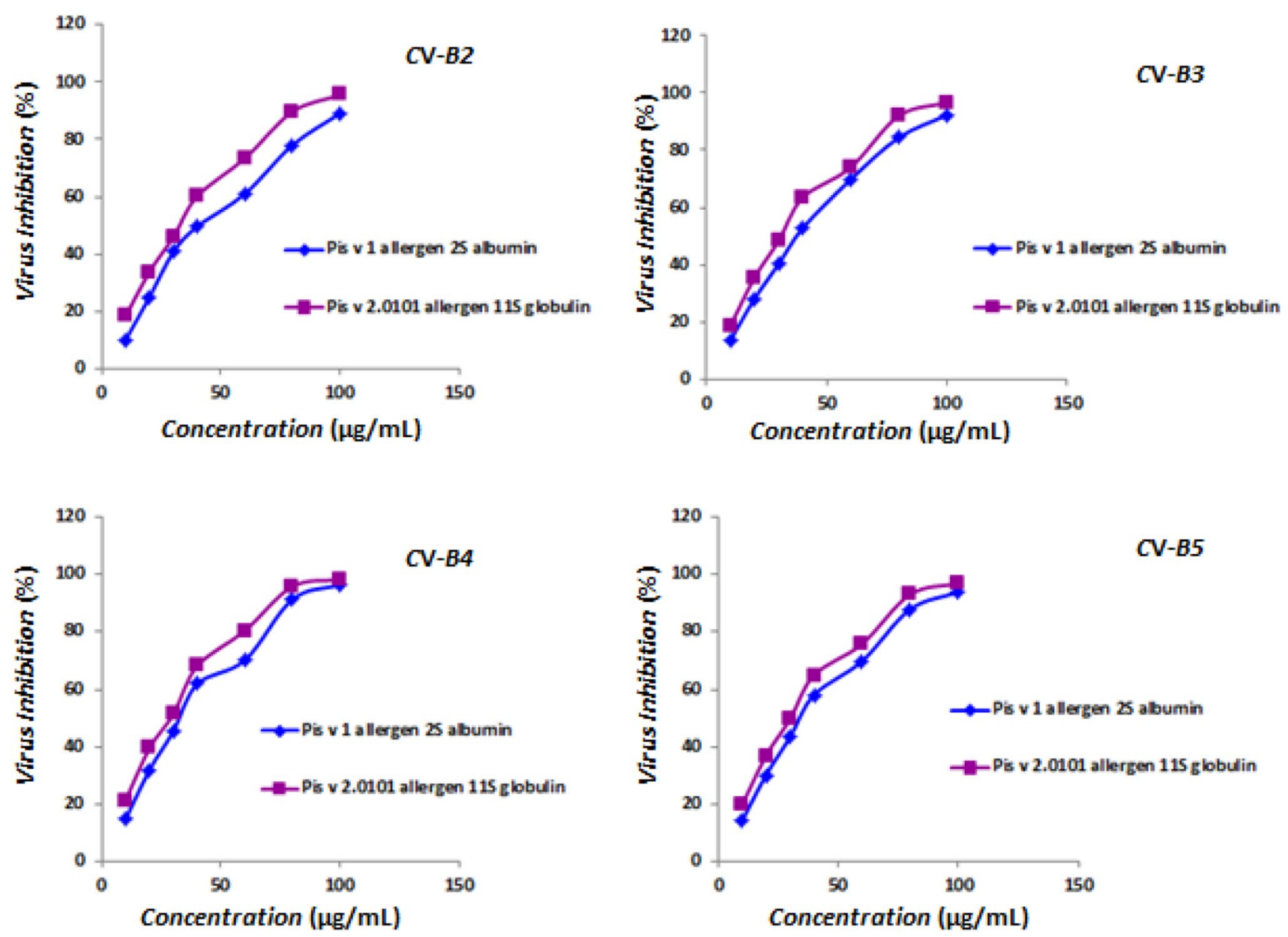

Fig. 3 Antiviral activity of Pis v 1 allergen $2 \mathrm{~S}$ albumin and Pis v 2.0101 allergen $11 \mathrm{~S}$ globulin against a Coxsackie virus B2; b Coxsackie virus B3; c Coxsackie virus B4 and $\mathbf{d}$ Coxsackie virus B5

Table 4 Virucidal activity of Pis v 1 and Pis v 2.0101

\begin{tabular}{|c|c|c|c|c|c|c|}
\hline \multirow[t]{2}{*}{ Coxsackie virus } & \multicolumn{3}{|l|}{ Pis v 1} & \multicolumn{3}{|l|}{ Pis v 2.0101} \\
\hline & $\mathrm{CC}_{50}{ }^{\mathrm{a}}$ & $\mathrm{IC}_{50}^{\mathrm{b}}$ & $\mathrm{SI}^{\mathrm{c}}$ & $\mathrm{CC}_{50}$ & $\mathrm{IC}_{50}$ & SI \\
\hline$C \mathrm{~V}-B 2$ & $352.20 \pm 1.03$ & $48.05 \pm 0.90$ & 7.33 & $648.75 \pm 1.02$ & $37.50 \pm 1.01$ & 17.30 \\
\hline$C \mathrm{~V}-B 3$ & $516.25 \pm 1.05$ & $43.75 \pm 1.01$ & 11.80 & $649.88 \pm 1.01$ & $35.61 \pm 1.03$ & 18.25 \\
\hline$C \mathrm{~V}-B 4$ & $633.88 \pm 1.01$ & $38.77 \pm 1.02$ & 16.35 & $710.30 \pm 1.03$ & $30.20 \pm 1.01$ & 23.52 \\
\hline$C \mathrm{~V}-B 5$ & $586.73 \pm 1.02$ & $41.29 \pm 1.03$ & 14.21 & $648.42 \pm 1.03$ & $31.77 \pm 1.02$ & 20.41 \\
\hline
\end{tabular}

${ }^{\text {a }}$ The $50 \%$ cytotoxic concentration for target cells $(\mu \mathrm{g} / \mathrm{mL})$

${ }^{\mathrm{b}}$ The concentration of the sample required for $50 \%$ inhibition $(\mu \mathrm{g} / \mathrm{mL})$

${ }^{\mathrm{c}}$ Selectivity index

from the venom of Iranian honey bee, possesses broad antimicrobial spectra as well as anticancer properties [20]. By the advent of molecular biology techniques, many studies examined antibacterial, antifungal, antiviral, and anticancer activities of proteins isolated from different sources such as plants, mammals, marine invertebrates, and insects. For example, the peptide obtained from the wheat endosperm, purothionin, showed antibiotic activities [15]. The cytoplasmic membranes of microbes are lipid-rich and the antimicrobial proteins can easily interact with the cytoplasmic membrane of pathogens using their charged- hydrophobic structure [17]. Based on our antimicrobial assessments, the most susceptible strains were Gram-positive bacteria. Biological evaluations revealed that it is easier for antimicrobial proteins to enter Gram-positive peptidoglycan layer compared to Gram-negative hydrophilic lipopolysaccharides 
Table 5 Cytotoxic activity $\left(\mathrm{IC}_{50}\right)$ of Pis v 1 and Pis v 2.0101

\begin{tabular}{llll}
\hline Cell line & Pis v 1 & Pis v 2.0101 & Doxorubicin \\
\hline MCF-7 & $25.71 \pm 0.94$ & $28.11 \pm 0.88$ & $0.78 \pm 0.05$ \\
A2780 & $30.06 \pm 0.71$ & $33.95 \pm 0.42$ & $0.61 \pm 0.02$ \\
PC3 & $31.74 \pm 0.63$ & $34.05 \pm 0.42$ & $0.44 \pm 0.05$ \\
DU-145 & $34.52 \pm 0.90$ & $38.63 \pm 0.80$ & $0.98 \pm 0.05$ \\
U-87-MG & $21.09 \pm 0.55$ & $26.34 \pm 0.88$ & $0.39 \pm 0.05$ \\
HTC & $25.71 \pm 0.94$ & $28.11 \pm 0.88$ & $0.78 \pm 0.05$ \\
\hline
\end{tabular}

Data are shown as mean $( \pm \mathrm{SD})$

$\mathrm{IC}_{50}$ : the concentration required for $50 \%$ inhibition $(\mu \mathrm{g} / \mathrm{mL})$

(LPS) which show higher degree of resistance towards hydrophobic antimicrobial compounds [23].

Recently, many viral diseases were treated with a combination of synthetic drugs which improve sustained virological response, but also produce adverse side effects including anemia and gastrointestinal symptoms [14]. In addition, antimicrobial proteins can exhibit antitumor and antiviral effects [27]. It has been reported that two allergens of pistachio inhibited several group B Coxsackie viruses. Pharmacological activities of pistachio allergens were attributed to their antiviral potential. Our data showed that both allergens, markedly affected $C V-B 2-5$ viability. Viral membrane fusion inhibitory activity of these proteins may be related to their lipopeptide- based structure [37]. It was indicated that tryptophan- rich, C8 (Ac-Trp-Glu-Asp-Trp-Val-Gly-Trp-Ile$\mathrm{NH} 2$ ) plays a major role against the membrane- proximal external region of the feline immune deficiency virus (FIV) [8]. It seems that the inhibitory action is related to adsorption of the peptide on the plasma membrane of the target cell, where it can inhibit interactions between virus fusion glycoprotein [7]. Adsorbed peptide supports the cell from the fusion glycoprotein of the virus and it is directly due to the fundamental peptide; however, small peptides may exhibit no antiviral activity because of their conformational instability [8]. In another study using FTIR spectroscopy, a secondary structure consisting of an $\mathrm{N}$-terminal beta-sheet along with a turn and C-terminal beta-sheet was introduced as a new class of anti-HCV compounds [14].

Proteins have been regarded as candidates for treatment of cancer or inflammatory diseases and were shown to trigger apoptosis and prevent angiogenesis. Anticancer proteins are able to stimulate host defense system cells and tissues via direct and indirect interaction with host's genes and proteins [27].

In our study, pistachio allergens produced potent cytotoxicity in a concentration- dependent manner against all six cell lines. Interestingly, HTC cells were found to be more sensitive to the cytotoxic effects of both allergens compared to the other cell lines. In a previous study, R-lycosin-I modified by amino acid substitution from lycosin-I, showed anticancer activity and inhibited cell proliferation [12]. In another research, fatty acids with different chain lengths were introduced to the $\mathrm{N}$-terminal of R-lycosin-I; this modification increased cytotoxic activity of these lipopeptides against A549 cells [12]. Also, Tag7 was reported to be an innate immune protein that is involved in the antibacterial and antitumor effects [24]. Moreover, Tag7 complex with Hsp70 showed cytotoxic effects in many tumor cell lines. It seems that Tag7 can activate cytotoxic lymphocyte subpopulations [25]. Cytotoxicity of proteins may be exerted through different mechanisms including disruption of cell membrane integrity via depolarization, reducing the activity of membrane- bound enzymes, modification of the mevalonate pathway of metabolism and/or induction of apoptosis [35].

\section{Conclusion}

The two allergens isolated from pistachio in this study, presented considerable effects against biofilm-related infections, $C \mathrm{~V}-B 2-5$, and several cell lines. These observations could be used as a basis for future experiments to further evaluate potential therapeutic applications of these proteins.

Acknowledgements The authors kindly thank Pharmaceutical Research Center, Pharmaceutical Technology Institute, Mashhad University of Medical Sciences, Mashhad, Iran.

\section{Compliance with ethical standards}

Conflicts of interest The authors declare that they have no conflicts of interest.

\section{References}

1. K. Ahn, L. Bardina, G. Grishina, K. Beyer, H. Sampson, Identification of two pistachio allergens, Pis v 1 and Pis v 2, belonging to the $2 \mathrm{~S}$ albumin and $11 \mathrm{~S}$ globulin family. Clin. Exp. Allergy 39, 926-934 (2009)

2. R. Anbuchezian, S. Ravichandran, D.K. Rajan, S. Tilivi, S.P. Devi, Identification and functional characterization of antimicrobial peptide from the marine crab Dromia dehaani. Microb. Pathog. 125, 60-65 (2018)

3. P. Arulmozhi, S. Vijayakumar, T. Kumar, Phytochemical analysis and antimicrobial activity of some medicinal plants against selected pathogenic microorganisms. Microb. Pathog. 123, 219226 (2018)

4. A.V. Barros, L.M. Araújo, F.F. de Oliveira, A.O. da Conceição, I.C. Simoni, M.J.B. Fernandes, C.W. Arns, Avaliação in vitro do potencial antiviral de Guettarda angelica contra herpesvírus animais. Acta Scientiae Veterinariae 40, 1068 (2012)

5. M.A. Benkahla, E.K. Alidjinou, F. Sane, R. Desailloud, D. Hober, Fluoxetine can inhibit coxsackievirus-B4 E2 in vitro and in vivo. Antiviral Res. 159, 130-133 (2018)

6. L. Chiang, W. Chiang, M. Chang, L. Ng, C. Lin, Antiviral activity of Plantago major extracts and related compounds in vitro. Antiviral Res. 55, 53-62 (2002) 
7. A.M. D'Ursi et al., Development of antiviral fusion inhibitors: short modified peptides derived from the transmembrane glycoprotein of feline immunodeficiency virus. ChemBioChem $\mathbf{7}$, 774-779 (2006)

8. G. D'Errico, G. Vitiello, A.M. D'Ursi, D. Marsh, Interaction of short modified peptides deriving from glycoprotein gp36 of feline immunodeficiency virus with phospholipid membranes. Eur. Biophys. J. 38, 873-882 (2009)

9. M.L. Downs et al., Characterization of low molecular weight allergens from English walnut (Juglans regia). J. Agric. Food Chem. 62, 11767-11775 (2014)

10. FAOSTAT, Food and Agriculture Organization of the United Nations (Italy, Rome, 2018)

11. S. Geiselhart, K. Hoffmann-Sommergruber, M. Bublin, Tree nut allergens. Mol. Immunol. 100, 71-81 (2018)

12. C. Jian et al., The roles of fatty-acid modification in the activity of the anticancer peptide R-lycosin-I. Mol. Pharm. 15, 4612-4620 (2018)

13. E.A. Kapp et al., Mining a tandem mass spectrometry database to determine the trends and global factors influencing peptide fragmentation. Anal. Chem. 75, 6251-6264 (2003)

14. R. Khachatoorian et al., Structural characterization of the HSP70 interaction domain of the hepatitis C viral protein NS5A. Virology 475, 46-55 (2015)

15. T. Nakatsuji, R.L. Gallo, Antimicrobial peptides: old molecules with new ideas. J. Investig. Dermatol. 132, 887-895 (2012)

16. C.E. Palma, P.S. Cruz, D.T.C. Cruz, A.M.S. Bugayong, A.L. Castillo, Chemical composition and cytotoxicity of Philippine calamansi essential oil. Ind. Crops Prod. 128, 108-114 (2019)

17. R. Rathinakumar, W.F. Walkenhorst, W.C. Wimley, Broad-spectrum antimicrobial peptides by rational combinatorial design and high-throughput screening: the importance of interfacial activity. J. Am. Chem. Soc. 131, 7609-7617 (2009)

18. J. Sealey-Voyksner, J. Zweigenbaum, R. Voyksner, Discovery of highly conserved unique peanut and tree nut peptides by LCMS/MS for multi-allergen detection. Food Chem. 194, 201-211 (2016)

19. J.A. Sealey-Voyksner, C. Khosla, R.D. Voyksner, J.W. Jorgenson, Novel aspects of quantitation of immunogenic wheat gluten peptides by liquid chromatography-mass spectrometry/mass spectrometry. J. Chromatogr. A. 1217, 4167-4183 (2010)

20. U. Shabir, S. Ali, A.R. Magray, B.A. Ganai, P. Firdous, T. Hassan, R. Nazir, Fish antimicrobial peptides (AMP's) as essential and promising molecular therapeutic agents: a review. Microb. Pathog. 114, 50-56 (2018)

21. A. Shakeri, J. Akhtari, V. Soheili, S.F. Taghizadeh, A. Sahebkar, R. Shaddel, J. Asili, Identification and biological activity of the volatile compounds of Glycyrrhiza triphylla Fisch. \& CA Mey. Microb. Pathog. 109, 39-44 (2017)

22. A. Shakeri et al., LC-ESI/LTQOrbitrap/MS/MS and GC-MS profiling of Stachys parviflora L. and evaluation of its biological activities. J. Pharm. Biomed. Anal. 168, 209-216 (2019)

23. A. Shakeri, F. Khakdan, V. Soheili, A. Sahebkar, G. Rassam, J. Asili, Chemical composition, antibacterial activity, and cytotoxicity of essential oil from Nepeta ucrainica L. spp. Kopetdaghensis. Ind. Crops Prod. 58, 315-321 (2014)

24. T.N. Sharapova, O.K. Ivanova, V.S. Prasolov, E.A. Romanova, L.P. Sashchenko, D.V. Yashin, Innate immunity protein Tag7 (PGRP-S) activates lymphocytes capable of Fasl-Fas-dependent contact killing of virus-infected cells. IUBMB Life 69, 971-977 (2017)

25. T.N. Sharapova, O.K. Ivanova, N.V. Soshnikova, E.A. Romanova, L.P. Sashchenko, D.V. Yashin, Innate immunity protein Tag7 induces 3 distinct populations of cytotoxic cells that use different mechanisms to exhibit their antitumor activity on human leukocyte antigen-deficient cancer cells. J. Innate Immun. 9, 598-608 (2017)

26. A. Snene et al., In vitro antimicrobial, antioxidant and antiviral activities of the essential oil and various extracts of wild (Daucus virgatus (Poir.) Maire) from Tunisia. Ind. Crops Prod. 109, 109-115 (2017)

27. S. Spänig, D. Heider, Encodings and models for antimicrobial peptide classification for multi-resistant pathogens. BioData Min. 12, 7 (2019)

28. S.F. Taghizadeh et al., Health risk assessment of heavy metals via dietary intake of five pistachio (Pistacia vera L.) cultivars collected from different geographical sites of Iran. Food Chem. Toxicol. 107, 99-107 (2017)

29. S.F. Taghizadeh, G. Davarynejad, J. Asili, B. Riahi-Zanjani, S.H. Nemati, G. Karimi, Chemical composition, antibacterial, antioxidant and cytotoxic evaluation of the essential oil from pistachio (Pistacia khinjuk) hull. Microb. Pathog. 124, 76-81 (2018)

30. S.F. Taghizadeh et al., Cumulative risk assessment of pesticide residues in different Iranian pistachio cultivars: applying the source specific HQS and adversity specific HIA approaches in real life risk simulations (RLRS). Toxicol. Lett. 313, 91-100 (2019)

31. S.F. Taghizadeh et al., Risk assessment of exposure to aflatoxin B1 and ochratoxin A through consumption of different Pistachio (Pistacia vera L.) cultivars collected from four geographical regions of Iran. Environ. Toxicol. Pharmacol. 61, 61-66 (2018)

32. S.F. Taghizadeh, R. Rezaee, G. Davarynejad, G. Karimi, S.H. Nemati, J. Asili, Phenolic profile and antioxidant activity of Pistacia vera var. Sarakhs hull and kernel extracts: the influence of different solvents. J. Food Meas. Charact. 12, 2138-2144 (2018)

33. S.F. Taghizadeh, R. Rezaee, M. Mehmandoust, F.S. Madarshahi, A. Tsatsakis, G. Karimi, Coronatine elicitation alters chemical composition and biological properties of cumin seed essential oil. Microb. Pathog. 130, 253-258 (2019)

34. M. Tavassoli, A. Afshari, D. DRĂGĂNESCU, A. LETIȚIA, Antimicrobial resistance of yersinia enterocolitica in different foods. A review. Farmacia 66, 399-407 (2018)

35. Z. Ye, S.-Z. He, Z.-H. Li, Effect of A $\beta$ protein on inhibiting proliferation and promoting apoptosis of retinal pigment epithelial cells. Int. J. Ophthalmol. 11, 929 (2018)

36. T. Yousaf et al., Phytochemical profiling and antiviral activity of Ajuga bracteosa, Ajuga parviflora, Berberis lycium and Citrus lemon against hepatitis $C$ virus. Microb. Pathog. 118, 154-158 (2018)

37. Y. Zhu, H. Chong, D. Yu, Y. Guo, Y. Zhou, Y. He, Design and characterization of cholesterylated peptide HIV-1/2 fusion inhibitors with extremely potent and long-lasting antiviral activity. J. Virol. 93, e02312-e02318 (2019)

Publisher's Note Springer Nature remains neutral with regard to jurisdictional claims in published maps and institutional affiliations. 